\title{
Development of Literary Anthropology through Thesis Writing as a Competitive Superior for the Future
}

\author{
Suwardi Endraswara \\ Yogyakarta State University \\ suwardi_endraswara@yahoo.com
}

\begin{abstract}
This paper aims to (1) describe the mapping of students'thesis writing of Javanese Language Education, Faculty of Languages and Arts, Yogyakarta State University to be more directed and quickly pass as needed; (2) to describe the strategic step of science development of Javanese literary anthropology as the competitive superior. This research is a descriptive research analysis that aims to perform meta-analysis on the results of studies in various concepts in the development of research umbrella on students' thesis writing. The results showed a mapping of students' thesis based on the research group of Javanese Literature Anthropology. The science of Anthropology of Javanese literature is more desirable for students, because it can combine the field of literature with other fields such as: (1) folklore, (2) culture, (3) pragmatic, (4) religion, and (5) art. After going through the assessment, it turns out that the field of Anthropology of Javanese Literature can be developed through interdisciplinary literature review. The results of this interdisciplinarystudy can give ideas to students' writing thesis fields as in (1) literary and religious studies, (2) literary and travel studies, (3) literary and gastronomic studies, (4) literary and political studies, (5) ) literary ethnographic studies, (6) literary postcolonial studies, (7) literary diaspora studies, (8) literary industrialization studies, and (9) karawitan (traditional Javanese instrument) literary studies. Studies of literary anthropology are done by students who write the thesis under supervision of research lecturers. In addition, mapping the field of science through thesis writing is further supported by mentors who are conducting similar research. By these means, students are expected to graduate faster. The thesis writing is projected to broaden the development of Javanese literary anthropology as a competitive superior in the future.
\end{abstract}

Keywords:development, literary anthropology, thesis, competitive superior.

\section{INTRODUCTION}

Literary anthropology is a new perspective for understanding literature from the cultural aspect. The development of the science of literary anthropology is urgent, because many students are interested in understanding literature from a cultural perspective. The definition of development is to empower literature studies to a more interdisciplinary course. Literature is a cultural documentation. Literary anthropology needs special development, among others through the writing of final task (thesis) and student scientific work. The development of scholarship of Program Studi Pendidikan Bahasa Jawa (PBJ)is conducted in line with the policies of the faculty and the university that has a leading reference in character education. Character education turns out to appear in many literary works. PBJhas a goal for investment of civilization, especially civilization with local culture (Java). Human civilization is largely determined by the quality of education. The development of education is an effort towards civilized people who are getting better over time. With education, competence to build human civilization will be obtained. Character education based on local cultural civilization will bring humanist competence. This is the assumption that only competent people can compete in the world of global civilization.

In this regard,PBJseeks to develop human resources to improve quality in two ways, namely (1) researchbased learning and (2) learning materials that are insightful to journal writing. From the two insights, the writing of the final project and student journals are led to produce works that have the value of literary anthropology. Through the research of literary works in the perspective of literary anthropology, students will master the cultural aspects of literature. These aspects become provisions to build the character of the nation, as a competence of civilization.

On the basis of the development program, it is expected that the PBJbecomes the agent of change to advance the world. Only competent people are capable of "changing the world". Professional change of language, literature, culture, and Javanese literature can be integrated through literary anthropological perspectives. In this way, the study program becomes a mainstay to prepare learners who are competent in their field. To achieve the projected competence, the adaptation of global and local sciences in the fields of language, literature, culture, and Javanese arts are required.

The scientific development of the study program, in addition to the reflected point in the writing of accredited national journal articles and indexed international journals, is also demonstrated by the participation of lecturers and students at national and international scientific forums both in country and internationally. It is necessary to provide opportunity for each lecturer and student to write a journal article, which can improve the quality of learning. As the PBJ intends to develop the 
field of literary anthropology, some numbers of local literary works that contains cultural context, and any other courses based on culture can be used to implement the value of literary anthropology.

The focus of literary anthropological scholars study can be attributed to wayang (Javanese traditional puppet show), Javanese tradition, and Javanese folklore, derived from the Ramayana epics. For the next five years, since 2018, the department's lecturers are directed to conduct Ramayana-based epic research, which is examined from the fields of language, literature, and culture. This research is then followed by the writing of student thesis, which elevates Ramayana epics with literary anthropological perspective. Therefore, this article attempts to compare the epic story of Javanese Ramayana and the Indian version.

(Note: in case of new term use, especially the term related to tradition, such as wayang, Ramayana, a brief explanation in bracket is necessary, assuming that not all the readers are familiar with it)

\section{DEVELOPMENT OF LITERARY ANTHROPOLOGY}

The development of literary anthropology needs to be persistently asserted since the works that depict the cultural ethnography are more appropriately understood from the perspective of literary anthropology. For the development of a literary anthropological perspective, it needs to be laid out, prioritized, and periodically designed. On that basis, this paper aims to (1) describe the mapping of students' writing the thesis of PBJto be more directed and fulfilled as needed; (2) to describe the strategic steps of science development of Javanese literary anthropology as the competitive superior. This is a descriptive analysis study that aims to perform metaanalysis of the results in various concepts in the development of "umbrella research" on the writing of thesis (final project). The characteristics of this methodology include meta-analyzes of interrelated study topics and the use of primary sources as data. The results showed a mapping of students' thesis based on research group (RG) field of Anthropology Literature.

The interdisciplinary mapping may result in diverse fields of thesis writing, such as in: (1) literary and religious studies, (2) literary and travel studies, (3) literary and gastronomic studies, (4) literary and political studies, 5) literary ethnographic studies, (6) literary postcolonial studies, (7) literary diaspora studies, (8) literary industrialization studies, and (9) studies of musical literature. Studies of literary anthropology by students who write the thesis is supervised by research lecturers. However, the lecturers of Javanese language study program starting in 2018 focus more on interdisciplinary understanding of the Ramayana epic.

Ramayanaepic in Java is very popular and has shifted. Since 1993, there has been a trace of transformation fromIndia Ramayana epics to Java as well as in various variations of literary and puppet texts [1]. Through a seminar at the State University of Yogyakarta Auditorium, it can be seen that the Ramayana epic hasexpanded into a wide variety of texts and performances. From the aesthetic side, Ramayana epics in Java have often changed from aspects of (1) characterizations, (2) storyline, (3) cultural background that accompanies the performance. Moreover Ramayana is not only embodied in the text, but has been changed and perceived in various forms of performances, thus allowing its tremendous transformation and development. The text of Ramayana was also in the time of R. Ng. Jasadipura has been transformed into Ramajarwa Epic.

In Java there is Pakem Ramayana (1978) [2], the play of Lahire Ramayana-Sakadang the two verses, there are good leadership values. A good leader has a strong spiritual base. Of course, without putting aside worldly capabilities such as governance, management, leadership, and so on. Javanese natural leadership Ramayana is naturally manifested in Asthabrata teachings, the eight teachings of the god. This teaching is clearly interesting from the perspective of literary anthropology. Of course the nuances of Indian and Javanese asthabrata teachings are variations of cultural emphasis.

From the Javanese side of the story, there is a composition entitled Ravana Putih (2013) by Sri Teddy Rusdy, that certainly experienced perceptions and changes here and there. Djoko Saryono also wrote a poem entitled Puisi Kemelut Cinta Rahwana Sehimpun. Sapardi Joko Damono also wrote a kind of essay poem entitled My Name is Sita (2016). From the data of the two works, it is clear that the Ramayana epics are not immune to change. The Ramayana epic actually experienced a rapid development, resulting in receptions, transformations, and changes that are harmonized with Javanese culture. Even according to [3], wayang in Java is often composed to describe the mind of the Javanese. On this basis, it is possible that the Ramayana epic in Java has more variations when compared to the Ramayana epics in India.

\section{THE MAPPING OF LITERARY ANTHROPOLOGY RESEARCH}

The mapping of literary anthropology research needs to be done, so that every five years there is a mature plan. When thesis students and lecturers are focused, the development of science of literary anthropology will expand widely. The focus of mapping the writing of journals by students and lecturers also needs to be done. Apparently the field of literary anthropology has been developed by [1] in their study of Javanese Literature Anthropology teacher's development. A literary anthropological perspective can be used to understand the epics of Javanese and Indian Ramayana, which have cultural differences.

From the perspective of literary anthropology, it can be seen that the Ramâyana epic was originally in Sanskrit in India. The word Ramayana is a combination of the words Rāma (Rama) and Ayana (Journey). This great work by the Indians is referred to as "the book." It contains an epic or heroic story from India and was composed by Walmiki about $400 \mathrm{BC}$. The contents of the book of Ramayana is composed of seven volumes 
(kanda) and composed in the form of poetry as much as 24,000 seloka?[1].

Of the seven kanda, it can be understood that from the perspective of literary anthropology there are variations of Indian and Javanese Ramayana epics. The Javanese poets do a lot of additions and creations that are tailored to the culture. The creation of the Ramayana epic in Java certainly adapts to the times, so its relevance persists. According to [4] there are teachings in the Ramayana epic which are still relevant today, despite differences with the Ramayana epics in India and Java. Suppose, Kumbakarna figure in Java by KGPAA. Mangkunagara IV was transformed into a hero figure in TripaEpic. Condition of this kind of character there are certainly variations with that occurred in India. Not to mention other figures such as Dasamuka, Sugriwa, Hanuman, Prabu Rama, Wibisana, and so on. It is also added with various versions of the story of the goddess Sinta in Java and India, which is interestingly discussed. Even in Java there is a opinion that King Rama is not a gentle figure, because when his wife was stolen by Dasamukaand who was not traced itself to Ngalengka. King Rama instead sent Anoman to become Anoman Duta's play in puppet.

Aesthetic changes in Indian and Javanese Ramayana, can also occur by the creativity of artists and authors. [5] actually has pointed out long time that the puppeteers often play puppets with carangan? play. The Ramayanacarpet is usually adapted to the environment. Therefore, it is very possible that the Ramayana epics were composed into various plays, such as Rama Tambak play, Sinta Obong, Anoman Obong, Anoman Duta, and so on. The various variations of the story turns out to embody a different storytelling from the Ramayana epics in India to Java. It is even possible that there is also a Java Ramayana epics reception to India.

The popularity of the epic Ramayana in Java has always been associated with the Ramayana epics in India. This is in view of [6] opinion that the Ramayana epics do have unique genetics in both India and Java. Both are often variations of the epic in accordance with the sociocultural conditions. That is why the Ramayana epics are growing in Java and India with a variety of unique stories.

The study of these two variations of the story can use a literary anthropological perspective. With this perspective, will unfold the myths of Indian and Javanese Ramayana. Even in Java often appear legends and inscriptions about the Ramayana nature of various tourist attractions, for example Ramayana in Goa Kiskenda, Kulon Progo Yogyakarta. It is possible that the Ramayana epic in Java has varied variations with Ramayana in India. This diversity is interesting to examine, because behind the variations there are various values, among others: (a) aesthetic values, (b) cultural values, and (c) pragmatic values that are often unexpected. In Java there is Ramayana Prambanan Ballet, Yogyakarta which differentiates Kumbakarna from Kumbakarna concept in India. Similarly, puppet plays such as Sinta Obong, Anoman Obong, and
Kumbakarna Gugur also create variations between Ramayana in Java and India.

\section{CONCLUSION}

From the above discussion, the development of the science of literary anthropology requires structuring and mapping. Structuring is related to the problem that the lecturers and students will be working on. Mapping is related to the subject of the object to be worked on. For that, it can be concluded that first, the development of scientific structuring of literary anthropology can be done synergistically between research supervisor (lecturer) and student of thesis writing. Structuring is associated with a literary anthropological comparative study. Second, the focus of thesis writing and research needs to be made gradually. The focus relates to the object of working on journal writing, which is working on Ramayana epics in the next five years.

\section{REFERENCE}

[1]. Endraswara, Suwardi. Ramayana Sepanjang Jaman. Yogyakarta: Yayasan Lembaga Studi Jawa. 1993.

[2]. Endraswara, Suwardi. Antropologi Sastra Jawa. Yogyakarta: Morfolingua. 2016.

[3]. Endraswara, Suwardi. Antropologi Wayang. Yogyakarta: Morfolingua. 2017.

[4]. Endraswara, Suwardi. Pengembangan Keilmuan Guru Besar Bidang Antropologi Sastra Jawa. Yogyakarta: WakilRektor I UNY. 2017.

[5]. Endraswara, Suwardi. Comparison Of Epic Ramayana Java And India in A Literature Antropological Perspective. New Delhi: Jawaharlal Nehru University. 2018.

[6]. Soetarsa, Slamet, Ki. Pakem Ramayana. Surakarta: Sadu Budi. 1978.

[7]. Aryandini, Woro. WayangdanLingkungan. Jakarta: Universitas Indonesia.

[8]. Abimanyu, Petir. Ajaran-Ajaran Emas Ramayana-Mahabharata. Yogyakarta: Laksana. 2014.

[9]. Groenendael, Victoria M. Clara van. Dalang Di BalikWayang. Jakarta: Grafiti.1987.

[10]. Haryanta. Bayang-Bayang Adiluhung dalam Wayang. Semarang. Dhahara Prize.1992.

[11]. Damono, Sapardi Djoko. Namaku Sita. Jakarta: Editum.2016.

[12]. Iser, Wolfgang. The Act of Reading: A Teory of Aesthetic Response. United States of America: The Johns Hopkins University Press Baltimore and London.1987.

[13]. Rusdy, Sri Teddy. RahwanaPutih. Jakarta: Yayasan Kertagama.2013

[14]. Somvir. "Bhattikavya Ravana-vadha" Yogyakarta: Seminar Ramayana; Transformasi dan Pengembangannya. 1998. 